\title{
Improving Mathematical Comprehension and Communication Skills of High School Students through the Quantum Teaching Model
}

\author{
${ }^{1}$ Farah Nurlia, ${ }^{2}$ Anizar Ahmad, ${ }^{3}$ Bansu Irianto Ansari* \\ ${ }^{1}$ Mathematics Education Program, Universitas Syiah Kuala, Banda Aceh, Indonesia \\ ${ }^{2}$ Early Childhood Education Program, Universitas Syiah Kuala, Banda Aceh, Indonesia \\ ${ }^{3}$ Mathematics Education Program, Universitas Serambi Mekkah, Banda Aceh, Indonesia
}

\begin{abstract}
The study aimed to investigate the improvement of the mathematical comprehension and communication skills of the students through learning the quantum teaching and conventional learning model. This research was an experimental study employing a pretest and posttest research design. The population of the study was all the Year 11 students from one of the senior high school in Banda Aceh, Indonesia, consisting of six classes. Two classes of samples were randomly selected, the experimental and the control classes. The instruments used in this research were a test of mathematical comprehension and communication skills. A statistical analysis employed to analyze the improvement of the mathematical comprehension and communication skills was t-test at the significance level of 0.005 . The result showed that the improvement of the mathematical comprehension and communication skills of the students through the quantum teaching model was better than the conventional learning model. this study recommends that teachers implement quantum teaching models.
\end{abstract}

Keywords: Quantum Teaching Model, Comprehension, Communication skills.

\section{Introduction}

The 2013 curriculum prioritizes the comprehension, skill and character education, where the students are required to comprehend the learning materials, and engage in discussions and presentations (Ministry of Education and Culture, 2013). The National Council of Teachers of Mathematics (NCTM, 2000) mentioned that the goal of mathematics learning is to equip students with a good understanding, reasoning, problemsolving, and connection skills as well as being able to communicate the learning outcomes to others. Comprehension is the essential skill to understand mathematical concepts. Hudojo (1998) argued that mathematical comprehension is the ability to interpret, give examples, classify, summarize, and compare a concept in solving mathematical problems.

Students' mathematical comprehension should not only include knowing and remembering mathematical formulas but also comprehending the concept thoroughly. Comprehending means being able to understand and see something from various aspects. In other words, the students are said to have good comprehension when they can explain the mathematical concepts in more details using their words. According to Murizal (2012), teachers still dominates the learning process in the classroom as the primary instructor and the students remain as the recipients of the Materials. The students find it difficult to define the learning materials using their sentences. Also, the students are often clueless about the application and real examples of the concepts learned.

In addition to the mathematical comprehension, students require mathematical communication skills in learning mathematics. Sumarmo (2012) asserted that the components of mathematics learning objectives are to communicate ideas with symbols, tables, diagrams, or mathematical expressions to clarify a situation or problem, and to develop positive attitude or appreciation concerning the benefits of mathematics in life, curiosity, attention and interest in learning mathematics, as well as to foster the persistence and confidence in problem-solving. Besides, Within (1992) argued that mathematical communication skill is the student's 
ability to express and interpret mathematical ideas verbally and in writing, or demonstrate the available information in a mathematical problem. According to Darkasyi (2014), the low mathematical communication skills and motivation of the junior high school students is due to the conventional approach still widely practiced by the teachers. This approach leads to a lack of students' mathematical communication skills and motivation.

The research conducted by Kusuma (2011) found that the level of mathematical comprehension of the senior high school students is relatively low suggested the number of students with good mathematical communication skills is limited. Therefore, it is pivotal for the students to accustom themselves in communicating their ideas to others verbally or in writing using their own words, so that other people can evaluate and respond to their interpretation. These activities enable students to comprehend or understand what they are doing meaningfully. This means that teachers should encourage students to improve their communication skills in each lesson.

Factors contributing to the lack of students'mathematical comprehension and communication skills can be viewed from various aspects including the aspects of students, teachers, learning methods, assessment, and government policies. Rahmat (2016) argued that one of the reasons for the lack of students' mathematical comprehension and communication skills is the teacher- centered learning. The students are not involved in constructing their knowledge and mainly accept the information from the teacher. The students are often unable to solve the problems that are different from the example. They can only imitate, and do the exercises following the given pattern without understanding the concept.

Previous studies show that students' mathematical comprehension and communication skills are relatively low, and the students are used to remembering the formulas without understanding and communication skills. To address these issues, teachers should implement the learning methods fostering the students to improve their mathematical comprehension and communication skills. Also, students find it difficult to comprehend the mathematical concepts soundly. To tackle this problem, the teachers need to employ the student-centered learning model and apply various teaching method emphasizing the scientific approach instead of one learning model only (such as direct instruction). The teachers should apply the most suitable learning model to improve students' mathematical comprehension and communication skills. The chosen learning model should contribute to eliminate mathematics anxiety and encourage students to build up their mathematical comprehension and communication skills. One of which is the quantum teaching model.

According to De Porter and Henarchi (2000), the quantum teaching model is a learning model enabling students to experience the mathematical problems directly, find the solution themselves, and engage in learning activities related to the competencies to be achieved. The quantum teaching model involves several learning stages, namely: growing, experiencing, naming, demonstrating, repeating and celebrating. A study conducted by Estu (2014) concluded that the application of the quantum teaching model employing the discussion method, and student worksheet improve the Year 10 students' learning outcomes concerning the topics of powers and roots. Based on the background previously illustrated, the study aims to examine the improvement of the mathematical comprehension and communication skills of the students experiencing the quantum teaching and conventional learning model.

\section{Method}

This research employed an experimental method of the quantitative research approach, more specifically a quasi-experimental design. Two groups of samples involved in this study: the experimental group taught using the quantum teaching learning model, and the control group taught using the conventional learning method. The pre-test and post-test, similar test instruments, were administered to both groups.

The research design used in this study was the Pretest-Posttest Group Control Design (Sugiyono, 2013). It was applied to investigate the improvement of students' mathematical comprehension and communication skills by administering tests before the treatment (pretest) and after the treatment (posttest). An overview of this design is presented in the following figure. 
Table 1: Research design

\begin{tabular}{|c|c|c|c|}
\hline Group & Pretest & Treatment & Postest \\
\hline Experiment & $\mathrm{O}$ & $\mathrm{X}$ & $\mathrm{O}$ \\
\hline Control & $\mathrm{O}$ & & $\mathrm{O}$ \\
\hline
\end{tabular}

Note:

$\mathrm{O}=$ Pretest and Posttest

$\mathrm{X}=$ Mathematics learning using the quantum teaching model

The population of this study was Year 11 students from one of the senior high school in Banda Aceh, Indonesia. This research was carried out in the second semester of the academic year 2017/2018. Two classes were randomly selected as the sample of the study.

The data were obtained from the instruments used, namely the test of comprehension and communication skills in the form of long answer questions. This type of questions was applied to examine the process of students' mathematical comprehension and communication skills, the accuracy and the systematic preparation of solution evidenced from the steps provided to solve the problems. The pretest was administered to examine the equality of the initial performance in the two classes while the posttest was administered to investigate the increase in students' mathematical comprehension and communication skills after the learning using the quantum teaching model. A t-test was used to examine the improvement of students' mathematical comprehension and communication skills.

The learning instruments used in the study were the test items that were first validated by experts and practitioners. The trial was also conducted to establish the validity and reliability of the test, followed by the revision to the instrument before it was used in the data collection.

Table 2: The validation of postest items of mathematical comprehension and communication skills

\begin{tabular}{|c|c|c|c|}
\hline Item number & R value & R table & Note \\
\hline 1 & 0.489 & 0.361 & Valid \\
\hline 2 & 0.771 & 0.361 & Valid \\
\hline 3 & 0.823 & 0.361 & Valid \\
\hline 4 & 0.633 & 0.361 & Valid \\
\hline
\end{tabular}

Table 3: Reliability Statistics

\begin{tabular}{|c|c|c|c|}
\hline $\begin{array}{c}\text { Cronbach's } \\
\text { Alpha }\end{array}$ & $\begin{array}{c}\text { Cronbach's Alpha } \\
\text { Based on } \\
\text { Standardized Items }\end{array}$ & $\begin{array}{c}\text { N of } \\
\text { Items }\end{array}$ & Interpretation \\
\hline 0.607 & 0.607 & 4 & Medium \\
\hline
\end{tabular}

Tests of mathematical comprehension consisted of two long answer questions, was administered at the beginning and the end of the learning using the quantum teaching and conventional learning model, to examine students' mathematical comprehension of the materials presented. The score of the test was given based on the level of each item. The indicators of mathematical comprehension test are shown in Table 4.

Table 4: The indicator of mathematical comprehension

\begin{tabular}{|c|l|l|}
\hline No & \multicolumn{1}{|c|}{$\begin{array}{c}\text { The indicators of mathematical } \\
\text { comprehension }\end{array}$} & \multicolumn{1}{c|}{ The indicator of the item } \\
\hline 1 & Restating a concept. & $\begin{array}{l}\text { The student can restate the meaning of a } \\
\text { concept }\end{array}$ \\
\hline 2 & Applying the concepts algorithmically. & $\begin{array}{l}\text { The student can use a concept to solve a } \\
\text { problem }\end{array}$ \\
\hline
\end{tabular}




\begin{tabular}{|c|l|l|}
\hline 3 & $\begin{array}{l}\text { Classifying objects based on the } \\
\text { characteristics of the concepts }\end{array}$ & $\begin{array}{l}\text { - The student can classify an object from } \\
\text { the materials based on the characteristics } \\
\text { of the concepts. }\end{array}$ \\
\hline 4 & $\begin{array}{l}\text { Developing the necessary and } \\
\text { sufficient }\end{array}$ & $\begin{array}{l}\text { - The student can understand the materials } \\
\text { by examining the conditions required or } \\
\text { not. }\end{array}$ \\
\hline
\end{tabular}

Tests of mathematical communication skills consist of two questions that were also provided at the beginning and the end of learning using quantum teaching and conventional learning models. The test aimed to determine students' mathematical communication skills concerning the materials presented and the grading was conducted based on the level of each item. The indicators of the mathematical communication skills test are displayed in Table 5.

Table 5: The indicators of the mathematical communication skills

\begin{tabular}{|c|c|c|}
\hline No & $\begin{array}{l}\text { The indicators of the mathematical } \\
\text { communication skills }\end{array}$ & The indicator of the items \\
\hline 1 & $\begin{array}{l}\text { Explaining the mathematical ideas, } \\
\text { situations, and relationships verbally using } \\
\text { real objects, images, graphics or algebra. }\end{array}$ & $\begin{array}{l}\text { - The student can present ideas of a } \\
\text { concept into the problem solving }\end{array}$ \\
\hline 2 & $\begin{array}{l}\text { Expressing daily activities in a } \\
\text { mathematical language or symbol. }\end{array}$ & $\begin{array}{l}\text { - The student can express daily activities } \\
\text { in a mathematical language or symbol }\end{array}$ \\
\hline 3 & $\begin{array}{l}\text { Linking real objects, pictures, and diagrams } \\
\text { Into mathematical ideas. }\end{array}$ & $\begin{array}{l}\text { The student can link real objects, } \\
\text { pictures, and diagrams into } \\
\text { mathematical ideas }\end{array}$ \\
\hline
\end{tabular}

\section{Results and Discussion}

The objective of this study was to examine the increase in students' mathematical comprehension and communication skills before and after learning with the Quantum, teaching model. Before the learning using the Quantum teaching model in the experimental class and the conventional learning in the control class was conducted, a pretest was administered for both classes to seek the students' initial abilities concerning mathematical comprehension and communication skills.

Table 6: The recapitulation of mathematical comprehension pretest

\begin{tabular}{|l|l|l|l|l|c|}
\hline \multicolumn{1}{|c|}{ Class } & N & Min & Max & $(\boldsymbol{x})$ & S \\
\hline Experiment & 30 & 25 & 75 & 49.50 & 12.52 \\
\hline Control & 30 & 25 & 75 & 49.77 & 13.63 \\
\hline
\end{tabular}

Table 7: The recapitulation of mathematical communication skills pretest

\begin{tabular}{|l|l|l|l|l|l|}
\hline \multicolumn{1}{|c|}{ Class } & N & Min & Max & $\overline{(\boldsymbol{x})}$ & S \\
\hline Experiment & 30 & 25 & 75 & 47.93 & 11.44 \\
\hline Control & 30 & 25 & 75 & 50.72 & 13.83 \\
\hline
\end{tabular}

Note:

$$
\begin{array}{lrl}
\mathrm{N} & =\text { The number of students } \quad \max \quad \begin{aligned}
\max & =\text { The highest score } \\
\bar{x} & =\text { Mean }
\end{aligned} \quad \mathrm{s} \quad=\text { Standard Deviation }
\end{array}
$$

The average score of the mathematical comprehension and communication skills pretest of the two classes was relatively different, with the control class having a relatively higher average than its counterpart. Meanwhile, the standard deviation values of both classes indicated that the data distribution on the mathematical comprehension and communication skills pretest is relatively different. To examine whether the mathematical comprehension and communication skills before the learning was different between the 
classes, statistical analysis tests were conducted, including the normality test, homogeneity of variance, and mean differences of mathematical comprehension and communication skills.

After conducting the learning using the Quantum Teaching learning model in the experimental class and the conventional learning model in the control class, the researcher administered a posttest to determine the increase in students' mathematical comprehension and communication skills in each class.

Table 8: The recapitulation of mathematical comprehension posttest

\begin{tabular}{|l|c|c|c|c|c|}
\hline \multicolumn{1}{|c|}{ Class } & N & Min & Max & $(\boldsymbol{x})$ & S \\
\hline Experiment & 30 & 60 & 95 & 77.52 & 10.16 \\
\hline Control & 30 & 45 & 92 & 65.82 & 12.67 \\
\hline
\end{tabular}

Table 9: The recapitulation of mathematical communication skills posttest

\begin{tabular}{|l|c|c|c|c|c|}
\hline \multicolumn{1}{|c|}{ Class } & N & Min & Max & $(\boldsymbol{x})$ & S \\
\hline Experiment & 30 & 55 & 95 & 77.52 & 10.16 \\
\hline Control & 30 & 45 & 92 & 66.12 & 11.62 \\
\hline
\end{tabular}

Note:

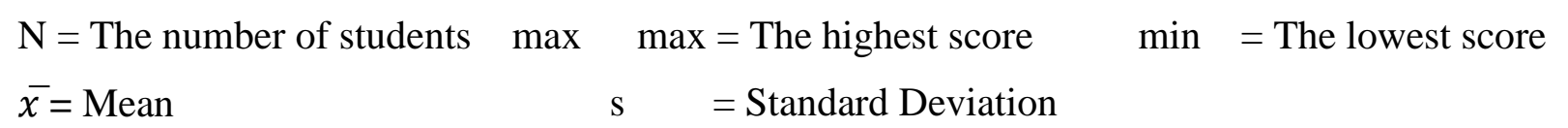

The average score of the mathematical comprehension and communication skills posttest in each class was relatively different, with the experimental class showing a relatively higher average than the control class. The average score of posttest in both classes also increased compared to the average score of the pretest.

Based on the average score of the pretest and posttest in the experimental and control classes, in general, there was an increase in the mathematical comprehension and communication skills in both classes. The improvement of students' mathematical comprehension and communication skills was tested by employing the normalized gain data (N-gain) analysis. The average normalized gain illustrates the increase in students' mathematical comprehension and communication skills after experiencing the learning using either the Quantum teaching learning models or the conventional learning approach. To ensure the differences in the increase in mathematical comprehension and communication skills of both classes, it was required to perform the $\mathrm{N}$-gain normality, the $\mathrm{N}$-gain variance homogeneity, and the $\mathrm{N}$-Gain mean difference tests.

The previous test results indicated that the N-gain data concerning the mathematical comprehension and communication skills of the experimental and control class were normally distributed and the variance was homogeneous. The mean difference test of the N-gain score was undertaken to prove that the increase in mathematical comprehension and communication skills of students experiencing learning with the Quantum Teaching learning model was better than their counterpart.

The analysis results of the pretest data of students' mathematical comprehension and communication skills showed that there was no significant difference in students' initial mathematical comprehension and communication skills before they learn with the Quantum Teaching Learning and the conventional learning model. However, the results of both descriptive analysis and statistical tests after the learning reported the increase in mathematical comprehension and communication skills of students in the Quantum Teaching learning was significantly better than those in the conventional learning classroom. The improvement of students' mathematical comprehension and communication skills are indicated by the higher average N-gain score in the experimental class compared to the control class. It suggests that students can understand well the concepts of the problems provided in the learning using the Quantum, Teaching model.

This is in accordance with Trianto (2010) stating that when students independently try to find solutions to the problems and the related knowledge, they will produce meaningful knowledge. The results of this study also reinforce research findings of Sunaryo (2014) concluding that the improvement of mathematical 
creativity and communication skills of students taught by the Quantum Teaching learning model is better than those using the direct learning; student attitudes concerning the implementation of Quantum Teaching learning model are positive.

\section{Conclusion}

Based on the analysis and the discussion, it can be concluded that: 1) the improvement of the mathematical comprehension of students experiencing the Quantum teaching learning is better than those obtaining the conventional learning and 2) the improvement of mathematical

Communication skills of students experiencing the Quantum teaching learning is better than those in the conventional learning.

\section{Reference}

[1.] Darkasy, M. (2014). Peningkatan Kemampuan Komunikasi Matematis dan Motivasi Siswa dengan Pembelajaran Pendekatan Quantum Learning pada Siswa SMP Negeri 5 Lhokseumawe. Jurnal Didaktik Matematika, 1(1), 21-34.

[2.] De Porter,B., \& Hernachi, M. (2000). Quantum Learning: Membiasakan Belajar Nyaman dan Menyenangkan.(Terjemahan Alawiyah Abdurrahman). Bandung: Kaifa.

[3.] Estu, H. (2014). Penerapan Model Pembelajaran Quantum Teaching dengan Metode Diskusi Berbantuan Lembar Kerja Siswa (LKS) untuk Meningkatkan Hasil Belajar Materi Bentuk Pangkat dan Akar Pada Siswa Kelas X. Jurnal Ilmiah Pendidikan Matematika, 3(2), 390-397.

[4.] Hudojo, D. (1998). Teori Belajar dalam Proses Belajar Mengajar Matematika. Jakarta: Depdikbud.

[5.] Kusuma, D. A. (2011). Meningkatkan Kemampuan Komunikasi Matematika Siswa SLTP dengan Menggunakan Metode Inkuiri.Thesis, Bnadung: UPI, unpublished.

[6.] Ministry of Education and Culture. (2013). Modul Pelatihan Implementasi Kurikulum 2013. Jakarta.

[7.] Murizal, A. (2012). Pemahaman Konsep Matematis dan Model Pembelajaran Quantum Teaching. Jurnal Pendidikan Matematika, 1(1), 19-23.

[8.] NCTM. (2000). Principles and Standar for Scholl Matematics. USA: NCTM.

[9.] Rahmat. (2016). Peningkatan Kemampuan Pemahaman dan Komunikasi Matematis Siswa Madrasah Aliyah melalui Model Pembelajaran Kooperatif Tipe Jigsaw. Thesis, Banda Aceh: Pasca Sarjana Pendidikan Matematika, unpublished.

[10.] Sugiyono.(2013). Metode Penelitian Kuantitatif, Kualitatif dan Kombinasi (Mixed Methods). Bandung: Alfabeta.

[11.] Sumarmo, U. (2012). Pengukuran dan Evaluasi dalam Pengajaran Matematika. Bandung, unpublished.

[12.] Sunaryo, Y. (2014). Model Pembelajaran Berbasis Masalah untuk Meningkatkan Kemampuan Berpikir Kritis dan Kreatif Matematik Siswa SMA di Kota Tasikmalaya. Jurnal Pendidikan dan Keguruan, 1(2), 41-51.

[13.] Trianto. (2010). Mendesain Model Pembelajaran Inovatif-Progresif. Jakarta: Kencana Prenada Media Group.

[14.] Wardani, S. (2008). Analisis SI dan SKL Mata Pelajaran Metamatika SMP/MTs untuk Optimalisasi Tujuan Mata Pelajaran Matematika. Yogyakarta: Depdiknas.

[15.] Within, (1992). Mathematics Task Centre Proffesional Development and Problem Solving. In J. Wakefield and L. American Education Research Journal, 62(14). 